\title{
Fetal hemoglobin levels are related to metabolic control in diabetic subjects
}

V.C. Pardini1,2,

I.M.N. Victória²,

F.B. Pieroni ${ }^{2}$, G. M ilagres $^{2}$,

P.D. Nascimento ${ }^{3}$, G. Velho 4 , S. Purisch ${ }^{2}$ and $\mathrm{H}$. Pardini ${ }^{1}$
${ }^{1}$ Instituto de Patologia Clínica H. Pardini, Belo Horizonte, MG, Brasil

${ }^{2}$ Centro de Pesquisas da Endocrinologia, Santa Casa de Belo Horizonte, Belo Horizonte, MG, Brasil

${ }^{3}$ Felício Rocho Hospital, Belo Horizonte, MG, Brasil

4IN SERM U 342, H ôpital Saint-Vincent-de-Paul, Paris, France

\section{Correspondence}

V.C. Pardini

Instituto de Patologia Clínica

H. Pardini

Rua Aimorés, 33

30140-070 Belo Horizonte, MG

Brasil

Fax: +55-31-225-1272

E-mail: vpardini@ labhpardini.com.br

Received August 4, 1998

Accepted February 22, 1999

\section{Abstract}

We have investigated the relationship between fetal hemoglobin $(\mathrm{HbF})$ levels and metabolic control in subjects with insulin-dependent $(\mathrm{N}=79)$ and non-insulin-dependent diabetes mellitus $(\mathrm{N}=242)$. $\mathrm{HbF}$ and hemoglobin A1c (HbA1c) levels were increased in subjects with type 1 and type 2 diabetes as compared to levels in nondiabetic individuals $(\mathrm{P}<0.0001)$, and were significantly higher in type 1 than in type 2 diabetes subjects. Lower levels of $\mathrm{HbA} 1 \mathrm{c}$ and $\mathrm{HbF}$ were observed in type 2 diabetes subjects treated by diet, intermediate levels in those treated with oral hypoglycemic agents, and higher levels in those treated with insulin. $\mathrm{HbF}$ and $\mathrm{HbA} 1 \mathrm{c}$ levels were correlated in type 1 diabetes $\left(\mathrm{R}^{2}=0.57, \mathrm{P}<0.0001\right)$ and type 2 diabetes $\left(\mathrm{R}^{2}=0.58\right.$, $\mathrm{P}<0.0001)$ subjects. Following intense treatment, twelve diabetic patients showed significant improvement both in $\mathrm{HbA} 1 \mathrm{c}$ and $\mathrm{HbF}$ values. We conclude that increased $\mathrm{HbF}$ levels reflect poor metabolic control in subjects with diabetes mellitus.

\section{Introduction}

Several hemoglobin subfractions are formed by glycation of hemoglobin $\mathrm{A}(\mathrm{HbA})$, including HbAla, HbA1b, the labile intermediate form (Hb-L-A 1c) and glycated hemoglobin A1c (HbAlc). HbA1c is formed in erythrocytes by a post-translational non-enzymatic two-step reaction. Glucose is first linked to the $\mathrm{N}$-terminal valine residue of the subsequently undergoes an Amadori rearrangement to yield the stable form. $\mathrm{HbA} 1 \mathrm{c}$ levels reflect the average blood glucose conbeta chain of HbA forming Hb-L-A 1c, which

\section{Key words}

- Fetal hemoglobin

- HbAlc

- Glycated hemoglobin

- Diabetes mellitus

- Type 1 diabetes

- Type 2 diabetes centration in the preceding 2 to 3 months $(1,2)$, and the measurement of $\mathrm{HbA} 1 \mathrm{c}$ has become an important reference value in monitoring the treatment of diabetes $(3,4)$.

Fetal hemoglobin $(\mathrm{HbF})$ is produced in a subpopulation of erythrocytes termed " $\mathrm{F}$ cells" and is the predominant hemoglobin in fetal life and early infancy. During the first year of life, $\mathrm{HbF}$ is gradually replaced by hemoglobin A, and only small amounts of $\mathrm{HbF}(<1.0 \%)$ can be found in adult life (5). $\mathrm{HbF}$ levels were shown to be increased in some subjects with type 1 diabetes (6-8), but data on $\mathrm{HbF}$ levels in type 1 diabetes are 
scarce. Moreover, no data are available for subjects with type 2 diabetes, and the correlation of $\mathrm{HbF}$ levels with the quality of metabolic control in diabetic subjects remains unclear. In the present study, we have investigated the relation between $\mathrm{HbF}$ and metabolic control in subjects with type 1 and type 2 diabetes.

\section{Material and Methods}

\section{Subjects}

$\mathrm{HbA} 1 \mathrm{c}$ and $\mathrm{HbF}$ levels were measured in 79 subjects with type 1 diabetes and 242 subjects with type 2 diabetes. All subjects were outpatients in the diabetes clinics of the Santa Casa or the Felício Rocho Hospitals in the city of Belo Horizonte, Brazil. Diabetes mellitus was defined according to World Health Organization criteria (9). Ascertainment of type 1 diabetes was based on a diagnosis of diabetes before the age of 30 years, the presence of ketoacidosis or weight loss at diagnosis, insulin-dependence thereafter, and body mass index (BMI) $<25.0 \mathrm{~kg} /$ $\mathrm{m}^{2}$. Ascertainment of type 2 diabetes was based on the diagnosis of diabetes after the age of 40 years, with no signs of ketoacidosis. Insulin-treated type 2 diabetes subjects with a BMI $<28.0 \mathrm{~kg} / \mathrm{m}^{2}$ and subjects with diabetes diagnosed between 30 and 40 years were excluded to avoid misdiagnosis of type 1 diabetes. Individuals younger than 10 years and those presenting nephropathy were also excluded from the study. Two groups of healthy subjects matched by age with the type 1 and type 2 diabetes patients were used as controls. Demographic and clinical data of patients and controls are shown in Table 1. The protocol was approved by the Santa Casa Ethics Committee. Subjects gave informed consent to participate in the study.

$\mathrm{HbA} 1 \mathrm{c}$ and $\mathrm{HbF}$ were also measured in 12 diabetic subjects (3 type 1 and 9 type 2 diabetes) before and after 6 to 16 weeks (average 12 weeks) of intensive treatment, to test the effects of a better metabolic control on $\mathrm{HbF}$ levels. Frequent blood glucose testing and insulin dose adjustments were scheduled for the type 1 diabetes patients, while 10 units/day of insulin were added to the treatment of type 2 diabetes patients.

\section{HbAlc and $\mathrm{HbF}$ assay}

$\mathrm{HbAlc}$ and $\mathrm{HbF}$ were measured in whole blood plus EDTA with a high-performance liquid chromatography (HPLC) ion-exchange analyzer (Glycated Hemoglobin Analyser, Merck Hitachi L-9100, Tokyo, Japan). This

Table 1 - Demographic and biological profile of patients and controls.

Data are reported as means \pm SD. OHA, Oral hypoglycemic agents. ap $<0.05$ compared to control group 1; bP $<0.05$ compared to control group 2 (ANOVA); ${ }^{\mathrm{C}}<0.05$ compared to type 2 diabetes subjects (ANOVA followed by the Tukey-Kramer HSD test).

\begin{tabular}{lccccc}
\hline & $\begin{array}{c}\text { Type 1 } \\
\text { diabetes }\end{array}$ & $\begin{array}{c}\text { Control } \\
\text { group 1 }\end{array}$ & $\begin{array}{c}\text { Type 2 } \\
\text { diabetes }\end{array}$ & $\begin{array}{c}\text { Control } \\
\text { group 2 }\end{array}$ & P \\
\hline Subjects (N) & 78 & 129 & 242 & 81 & \\
Sex (M/F) & $34 / 44$ & $42 / 87$ & $107 / 135$ & $21 / 60$ & - \\
Age (years) & $25 \pm 12$ & $25 \pm 7$ & $60 \pm 12$ & $58 \pm 9$ & - \\
Age at diagnosis (years) & $12 \pm 7$ & - & $51 \pm 11$ & - & - \\
Treatment: diet/OHA/insulin (\%) & $0 / 0 / 100$ & - & $27 / 48 / 25$ & - & - \\
Fasting glucose (mM) & $10.1 \pm 4.9^{\mathrm{a}}$ & $4.6 \pm 0.4$ & $10.0 \pm 3.6^{\mathrm{b}}$ & $5.0 \pm 0.6$ & $<0.0001$ \\
HbAlc (\%) & $7.9 \pm 2.1^{\mathrm{ac}}$ & $3.5 \pm 0.4$ & $7.1 \pm 2.0^{\mathrm{b}}$ & $3.8 \pm 0.4$ & $<0.0001$ \\
HbF (\%) & $0.99 \pm 0.48^{\mathrm{ac}}$ & $0.51 \pm 0.34$ & $0.82 \pm 0.35^{\mathrm{b}}$ & $0.42 \pm 0.16$ & $<0.0001$
\end{tabular}




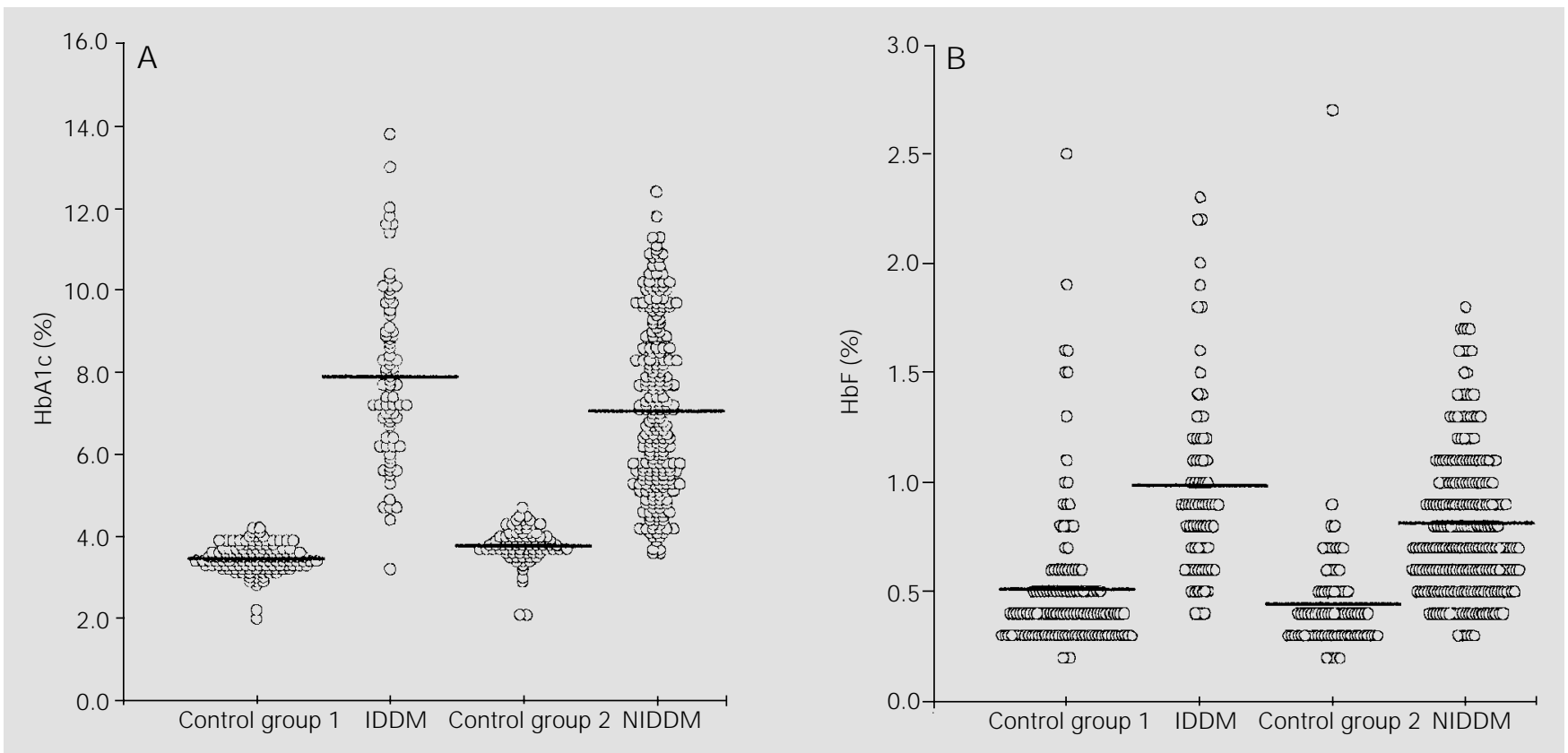

Figure 1 - HbAlc (A) and HbF (B) levels in IDDM (type 1 diabetes) and NIDDM (type 2 diabetes) subjects and in their respective control groups. Solid lines denote means.

is a fully automated analyzer consisting of an auto-sampler that withdraws the sample from the rack for dilution and hemolysis. The hemolysate is then pumped into an analytic separating column (CCMpack HB-S) warmed to $40^{\circ} \mathrm{C}$ by a column oven for high-speed analysis. The fractions (A1a, A1b, F, L-A1c, $\mathrm{A} 1 \mathrm{c}$ and $\mathrm{A} 0$ hemoglobin) eluted from the column are detected with a dual wavelength photometer and processed by a built-in microcomputer to identify and calculate the area of the peaks. The intra-assay and interassay coefficients of variation (CV) for $\mathrm{HbF}$ were 7.9 and $7.7 \%$, respectively. The intraassay $\mathrm{CV}$ for $\mathrm{HbA} 1 \mathrm{c}$ was less than $2.0 \%$, and the interassay $\mathrm{CV}$ was 3.8 or $5.6 \%$ for normal reference values or high values of $\mathrm{HbA} 1 \mathrm{c}$, respectively.

$\mathrm{HbF}$ levels were also measured in 17 subjects ( 8 type 2 diabetes and 9 control individuals) by the alkali denaturation method (10), which is considered to be the most sensitive method to detect low $\mathrm{HbF}$ levels. We found a strong correlation between the results obtained by HPLC and those ob- tained by the alkali denaturation method $\left(\mathrm{R}^{2}\right.$ $=0.90 ; \mathrm{P}<0.0001)$.

\section{Statistics}

Data are reported as means $\pm \mathrm{SD}$. Differences between groups were assessed by the paired Student $t$-test and by analysis of variance (ANOVA) followed by the TukeyKramer HSD (honestly significant difference) post-test for multiple comparisons (11). Linear regression analyses were performed to determine the associations of clinical and biological parameters. Data were analyzed with the SPSS for Windows 7.0 software (SPSS Inc., Chicago, IL).

\section{Results}

$\mathrm{HbA} 1 \mathrm{c}$ levels were increased in subjects with type 1 and type 2 diabetes as compared to subjects from control groups 1 and 2 (Table 1, Figure 1), and were significantly higher in type 1 than in type 2 diabetes subjects. HbF levels were increased in both 
Figure 2 - Correlations between $\mathrm{HbAlc}$ and $\mathrm{HbF}$ levels in (A) type 1 diabetes subjects $\left(R^{2}=0.57\right.$, $\mathrm{P}<0.0001)$, (B) type 2 diabetes subjects $\left(R^{2}=0.58, P<0.0001\right)$, (C) control group $1\left(R^{2}=0.007\right.$, $P=0.36)$, and $(D)$ control group $2\left(R^{2}=0.012, P=0.33\right)$. groups of diabetic patients as compared to the respective controls. $\mathrm{HbF}$ levels were also significantly higher in type 1 than in type 2 diabetes subjects. No sex-related differences were observed in $\mathrm{HbF}$ or $\mathrm{HbAlc}$ levels in any of the four groups (data not shown).

HbAlc levels in type 2 diabetes subjects treated with diet, oral hypoglycemic agents (OHA) and insulin were $5.8 \pm 1.7,7.2 \pm 1.9$ and $8.2 \pm 1.9 \%(\mathrm{P}<0.0001$; all Tukey-Kramer HSD comparisons between pairs $\mathrm{P}<0.05$ ), respectively. $\mathrm{HbF}$ levels in these groups were $0.62 \pm 0.24,0.83 \pm 0.33$ and $1.0 \pm 0.37 \%$ ( $\mathrm{P}<0.0001$; all Tukey-Kramer HSD comparisons between pairs $\mathrm{P}<0.05$ ), respectively.

$\mathrm{HbF}$ values were correlated to $\mathrm{HbA} 1 \mathrm{c}$ values in type $1\left(\mathrm{R}^{2}=0.57, \mathrm{P}<0.0001\right)$ and type 2 diabetes $\left(\mathrm{R}^{2}=0.58, \mathrm{P}<0.0001\right)$ subjects but not in control subjects (Figure 2). $\mathrm{HbA} 1 \mathrm{c}$ values were correlated with fasting plasma glucose values in diabetic subjects (pooled data $\mathrm{R}^{2}=0.29, \mathrm{P}<0.0001$ ) and mildly correlated in control subjects (pooled data $\mathrm{R}^{2}=0.04, \mathrm{P}<0.009$ ). HbF values were mildly
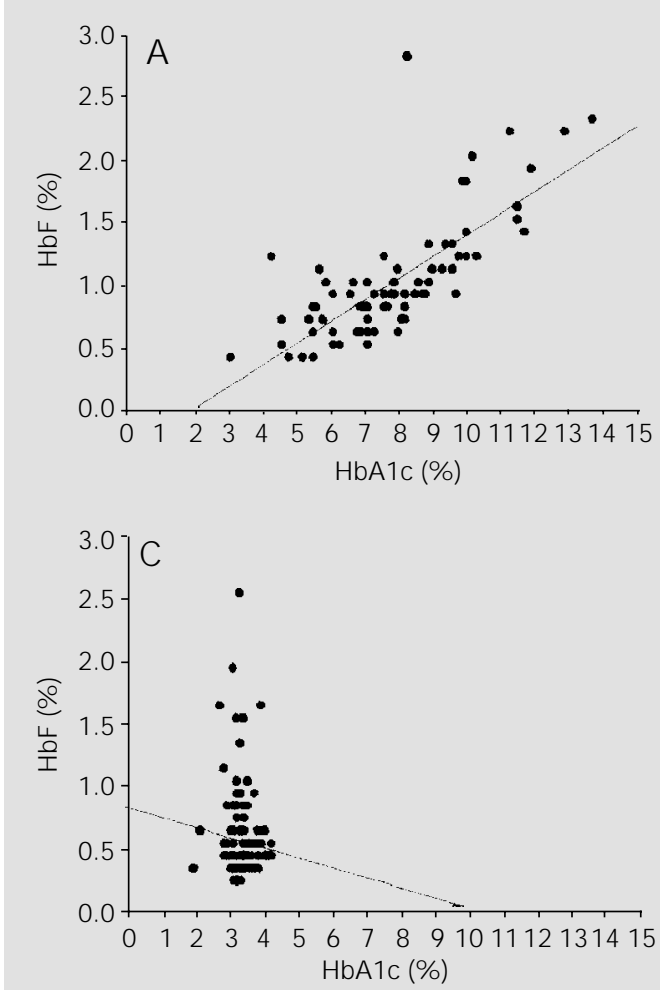

correlated with fasting plasma glucose values only in diabetic subjects (pooled data $\mathrm{R}^{2}$ $=0.09, \mathrm{P}<0.0001) . \mathrm{HbA} 1 \mathrm{c}$ and $\mathrm{HbF}$ values were correlated with the duration of diabetes in type 2 diabetes but not in type 1 diabetes subjects (data not shown).

Figure 3 shows $\mathrm{HbAlc}$ and $\mathrm{HbF}$ values in the 12 diabetic subjects who received intensive treatment. Basal and post-treatment $\mathrm{HbA} 1 \mathrm{c}$ levels were $7.9 \pm 1.6$ and $5.9 \pm 1.2 \%$ $(\mathrm{P}<0.0001)$, respectively. Concomitant basal and post-treatment $\mathrm{HbF}$ levels were $0.83 \pm$ 0.22 and $0.58 \pm 0.16 \%(\mathrm{P}<0.0001)$, respectively. Average improvement with treatment was $24.7 \%$ for $\mathrm{HbA} 1 \mathrm{c}$ values and $29.7 \%$ for $\mathrm{HbF}$ values (Figure 3 ). Improvements in these parameters were highly correlated $\left(\mathrm{R}^{2}=0.76\right.$; $\mathrm{P}<0.0001)$.

\section{Discussion}

We have observed increased levels of $\mathrm{HbF}$ in subjects with type 1 and type 2 diabetes. HbF levels were positively corre-
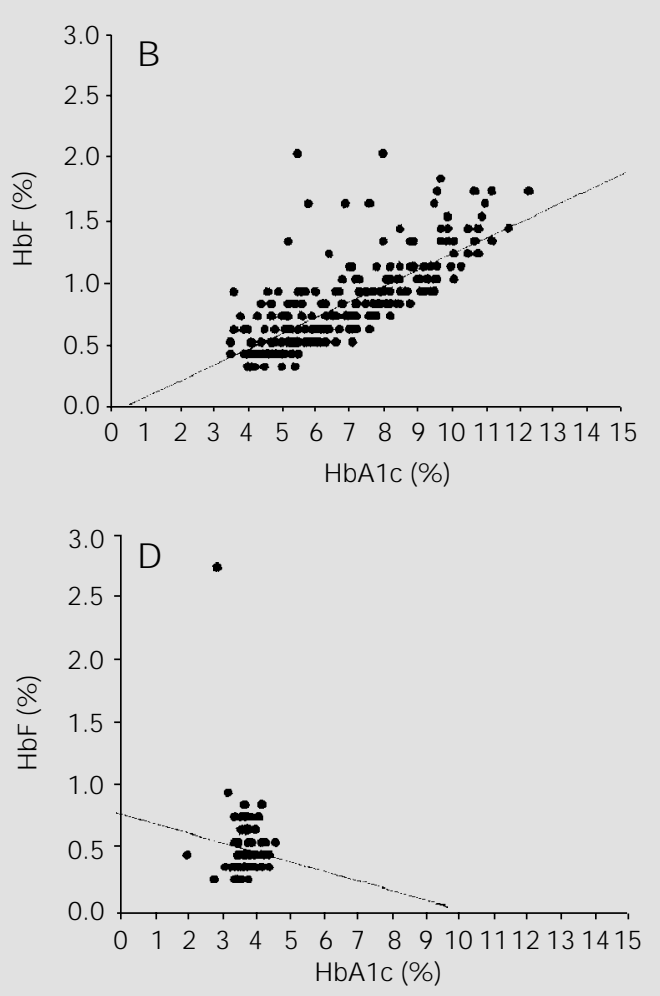
lated with $\mathrm{HbA} 1 \mathrm{c}$ levels in diabetic but not in nondiabetic individuals. Subjects with type 1 diabetes had higher levels of both $\mathrm{HbA} 1 \mathrm{c}$ and $\mathrm{HbF}$ than the subjects with type 2 diabetes. Furthermore, we have observed lower levels of both $\mathrm{HbAlc}$ and $\mathrm{HbF}$ in type 2 diabetes subjects who were treated with diet only, intermediate levels in those treated with OHA, and higher levels in the subjects treated with insulin. It is noteworthy that in type 1 diabetes subjects the prevalence of high $\mathrm{HbF}$ levels (see below) starts to increase gradually at an $\mathrm{HbA} 1 \mathrm{c}$ level of $7.7 \%$ and at an HbAlc level of $9.9 \%$, all diabetic patients presented high $\mathrm{HbF}$ levels (data not shown). In type 2 diabetes subjects, the prevalence of high $\mathrm{HbF}$ levels starts to increase at $\mathrm{HbA} 1 \mathrm{c}$ levels of $7.0 \%$ and at an $\mathrm{HbA} 1 \mathrm{c}$ level of $10.2 \%$ all patients presented high $\mathrm{HbF}$ levels. Since it is well established that $\mathrm{HbA} 1 \mathrm{c}$ levels reflect the quality of metabolic control in diabetic subjects, all these data suggest that high $\mathrm{HbF}$ levels might be associated with poor metabolic control. Moreover, we have observed that a decrease in $\mathrm{HbAlc}$ levels, and thus a better metabolic control, induced by intensive treatment in type 1 and type 2 diabetes subjects is associated with a decrease in $\mathrm{HbF}$ levels.

An increased prevalence of high $\mathrm{HbF}$ levels ranging from 13 to $38 \%$ of cases has been reported in type 1 diabetes subjects (6$8)$. Our data are in agreement with these reports. We have observed that $32 \%$ of the type 1 diabetes subjects of our cohort presented $\mathrm{HbF}$ levels higher than $1.0 \%$ (Figure 1 ), which is the level corresponding to the 90th percentile of $\mathrm{HbF}$ distribution in the control groups. Furthermore, $23 \%$ of the type 2 diabetes subjects in our cohort presented $\mathrm{HbF}$ levels higher than $1.0 \%$. To our knowledge, this is the first demonstration of increased $\mathrm{HbF}$ levels in type 2 diabetes patients. Note that $99 \%$ of the subjects with type 1 diabetes (all but one) and $97 \%$ of the subjects with type 2 diabetes (all but seven) presented HbAlc levels higher than $4.1 \%$
(Figure 1), which is the level corresponding to the 90th percentile of $\mathrm{HbA} 1 \mathrm{c}$ distribution in the control groups. These data suggest that, although $\mathrm{HbF}$ and $\mathrm{HbA} 1 \mathrm{c}$ are well correlated in diabetic subjects, $\mathrm{HbA} 1 \mathrm{c}$ is more accurate as a marker of diabetes.

The mechanisms leading to high $\mathrm{HbF}$ levels in diabetes are unknown. It has been suggested that high $\mathrm{HbF}$ levels could be related to a direct effect of insulin therapy $(7,12)$. However, our data do not agree with this hypothesis. Indeed, we have observed

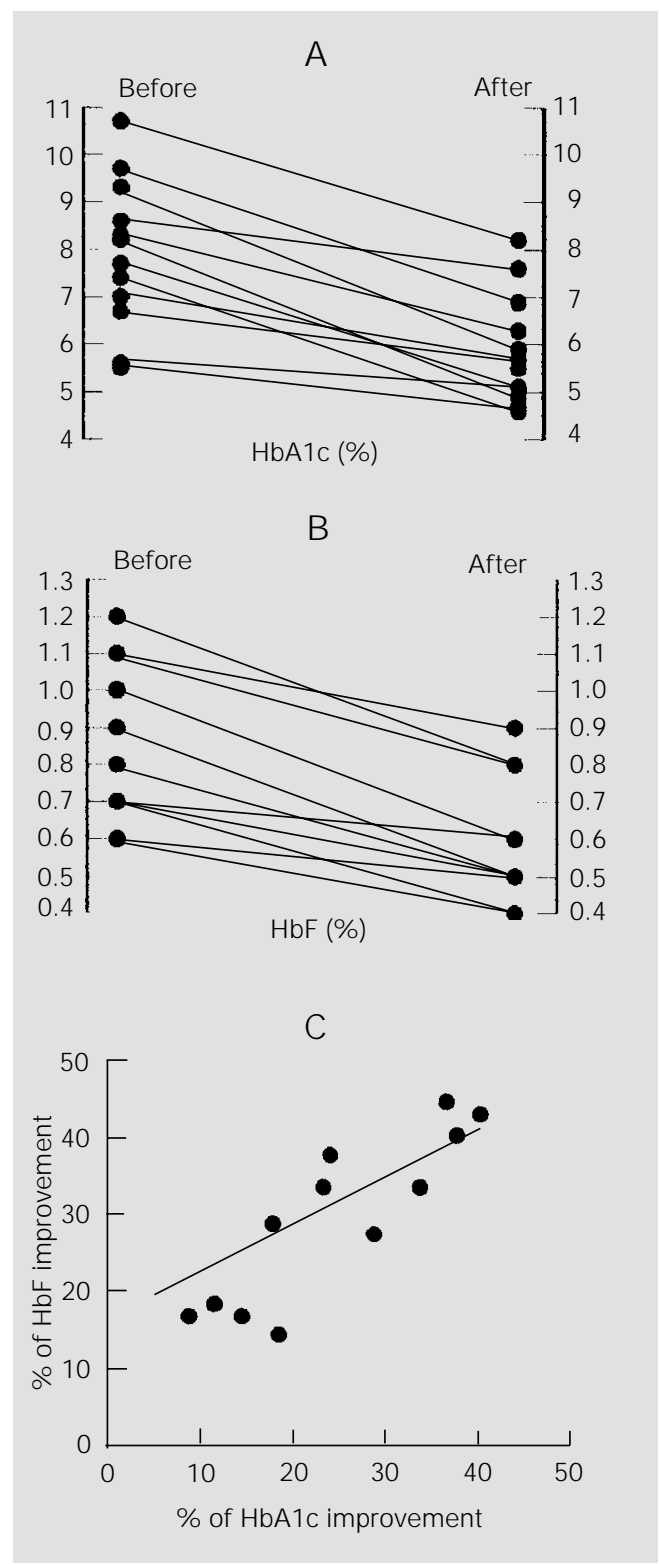

Figure 3 - $\mathrm{HbAlc}(\mathrm{A})$ and $\mathrm{HbF}(\mathrm{B})$ levels before and after intensive treatment. (C) Correlation between the percentage of improvement in $\mathrm{HbAlc}$ and $\mathrm{HbF}$ levels $\left(R^{2}=0.76, P<0.0001\right)$. 
that type 2 diabetes subjects with poorly controlled diabetes (high HbA1c levels) treated with diet or OHA also present high $\mathrm{HbF}$ levels which are positively correlated with $\mathrm{HbA1c}$ levels (data not shown). It is possible that $\mathrm{HbF}$ synthesis might be increased by stimuli resulting from poor metabolic control. Many studies have demonstrated that the expression of the $\gamma$-globin gene can be pharmacologically induced by short-chain fatty acids, especially those with 2 to 5 carbons like acetate and butyric acid (13-15). It has been speculated that products of ketoacidosis present in poorly controlled type 1 diabetes subjects could induce $\gamma$-globin gene expression, thus increasing $\mathrm{HbF}$ levels. Although type 2 diabetes patients are ketosis-resistant (16), several reports have shown that type 2 diabetes patients with poor metabolic control present increased circulating levels of short-chain fatty acids (17-21). Clearly, these mechanisms must be further investigated.

The observation of increased $\mathrm{HbF}$ levels in diabetes has practical consequences for the assessment of $\mathrm{HbA1c}$ in diabetic pa- tients. Since $\mathrm{HbF}$ migrates closer to $\mathrm{HbA} 1 \mathrm{c}$ in many electrophoresis and ion-exchange chromatography systems $(22,23)$, falsely increased levels of HbAlc may be detected if the technique does not separate the two hemoglobin fractions (24). In this study 34 diabetic patients presented high $\mathrm{HbF}$ levels $(>1.0 \%)$ with normal L-A1c $(>1.0 \%)$, which implies that there was no contamination between these $\mathrm{Hb}$ fractions in the chromatographic analysis (data not shown).

In conclusion, we observed high $\mathrm{HbF}$ levels in type 1 and type 2 diabetes subjects. $\mathrm{HbF}$ levels were highly correlated with $\mathrm{HbA1c}$ levels in diabetic but not in nondiabetic individuals. Increased $\mathrm{HbF}$ levels in diabetic subjects seem to reflect poor metabolic control. However, the mechanisms resulting in high $\mathrm{HbF}$ levels in diabetes mellitus remain poorly understood.

\section{Acknowledgments}

We thank Leida Maria Alves de Araújo for technical assistance.

\section{References}

1. Goldstein $D E$, Little RR, Wiedmeyer $H$, England JD \& Mackenzie EM (1986). Glycated hemoglobin: methodologies and clinical applications. Clinical Chemistry, 32 (Suppl 1): B64-B70.

2. Cefalu WT, Wang ZQ, Bell-Farrow A, Kiger FD \& Izlar C (1994). Glycohemoglobin measured by automated affinity HPLC correlates with both short-term and longterm antecedent glycemia. Clinical Chemistry, 40: 1317-1321.

3. J ovanovic L \& Peterson CM (1981). The clinical utility of glycosylated hemoglobin. American J ournal of Medicine, 70: 331338.

4. Larsen $M L$, Horder $M \&$ Mogensen $E F$ (1990). Effect of long-term monitoring of glycosylated hemoglobin levels in insulindependent diabetes mellitus. New England J ournal of Medicine, 323: 1021-1025.

5. Rochette J, Craig J E \& Thein SL (1994). Fetal hemoglobin levels in adults. Blood Reviews, 8: 213-224.
6. Mullis P, Schuler JJ \& Zuppinger K (1989). Increased prevalence of fetal haemoglobin in type 1 (insulin-dependent) diabetes mellitus. Diabetologia, 32: 227-230.

7. Koskinen LK, Latela JT \& Koivula TA (1994). Fetal hemoglobin in diabetic patients. Diabetes Care, 17: 828-831.

8. Diem $P$, Mullis $P$, Hirt $A$, Schuler $J$ J , Burgi W, Zuppinger K \& Teuscher A (1993). Fetal haemoglobin levels in adult type 1 (insulin-dependent) diabetic patients. Diabetologia, 36: 129-132.

9. World Health Organisation (1985). Diabetes mellitus. Report of a WHO Study Group. Technical Report Series, WHO, Geneva, No. 727.

10. Betke K, Marti HR \& Schlicht I (1959). Estimation of small percentages of fetal haemoglobin. Nature, 184: 1877-1878.

11. Kramer CY (1956). Extension of multiple range tests to group means with unequal numbers of replications. Biometrics, 12: 309-310.
12. Kilpatrick ES, Small $M$, Rumley $A$ \& Dominiczak MH (1993). Increased fetal hemoglobin in insulin-treated diabetes mellitus contributes to the imprecision of glycohemoglobin measurements. Clinical Chemistry, 39: 833-835.

13. Liakopoulou E, Blau CA, Li Q, J osephson $B$, Wolf J A, Fournarakis B, Aisys V, Dover G, Papayannopoulou T \& Stamatoyannopoulos G (1995). Stimulation of fetal hemoglobin production by short chain fatty acids. Blood, 86: 3227-3235.

14. Constantoulakis $P$, Papayannopoulou T \& Stamatoyannopoulos G (1988). Alphaamino-N-butyric acid stimulates fetal hemoglobin in the adult. Blood, 72: 19611967.

15. Stamatoyannopoulos G, Blau CA, Nakamoto B, Josephson B, Li Q, Liakopoulou E, Pace B, Papayannopoulou T, Brusilow SW \& Dover G (1994). Fetal hemoglobin induction by acetate, a product of butyrate catabolism. Blood, 84: 
3198-3204.

16. Nosadini $R$, Avogaro A, Doria A, Fioretto F, Trevisan R \& Morocutti A (1989). Ketone body metabolism: a physiological and clinical overview. Diabetes/Metabolism Reviews, 5: 299-319.

17. Papadakis M \& Grunfeld G (1986). Ketonuria in hospitalized patients with noninsulin-dependent diabetes mellitus. Diabetes Care, 9: 596-600.

18. Cook GA (1987). The hypoglycemic sulfonylurea glyburide and tolbutamide inhibit fatty acid oxidation by inhibiting carnitine palmitoyl-transferase. J ournal of Biological Chemistry, 262: 4968-4972.

19. Singh BM, Krentz AJ \& Nattrass M (1993).
Insulin resistance in the regulation of lipolysis and ketone body metabolism in non-insulin dependent diabetes is apparent at very low insulin concentrations. Diabetes Research and Clinical Practice, 20: 55-62.

20. Avogaro A, Valerio A, Gnudi L, Maran A, Zolli M, Duner E, Riccio A, Del Prato S, Tiengo A \& Nosadini R (1992). Ketone body metabolism in NIDDM. Effect of sulfonylurea treatment. Diabetes, 41: 968974.

21. Avogaro A, Crepaldi C, Miola M, Maran A, Pengo V, Tiengo A \& Del Prato S (1996). High blood ketone body concentration in type 2 non-insulin dependent diabetic pa- tients. J ournal of Endocrinological Investigation, 19: 99-105.

22. Gruber CA \& Krets MD (1979). Quantitation of hemoglobin $\mathrm{Al} a+b$ and hemoglobin Alc by automated "high performance" liquid chromatography. Clinical Chemistry, 25: 1970-1971.

23. Bulusu S (1995). Variant haemoglobin may affect measurements. British Medical J ournal, 310: 749-751.

24. Goldstein DE \& Little RR (1994). More than you ever wanted to know (but need to know) about glycohemoglobin testing (Editorial). Diabetes Care, 17: 938-939. 